\title{
Guidelines for applying budgeting as a tool for participatory democracy in Egypt
}

\author{
A. A. A. M. Ibrahim \\ Department of Architecture, Faculty of Engineering, \\ Cairo University, Egypt
}

\begin{abstract}
In spite of the progress made in the institutional and democratic components of Egypt governance, the real extent of decentralization has been limited mainly by the transfer of financial resources needed to match the devolved responsibilities. Therefore, participatory budgeting as a direct-democracy approach has been recently introduced in the frame of Egypt decentralization and strategic planning. From this view, the paper aims at comparing between the most innovative successful experiences regarding this process that have been implemented worldwide with some of the most illustrative case studies upon which this approach has been tested in Egypt in its different governorates. This would help in clarifying all the deficiencies incorporated within the implementation of this process on the local level, and consequently draws ways to overcome them. The paper would thus end up with the deduction of guidelines that can help in delivering the main goals of the targeted fiscal decentralization regarding the different aspects of the participatory budgeting including the initiation and implementation stages, financial aspects, citizen and governmental participation, legal, and territorial dimensions.
\end{abstract}

Keywords: participatory budgeting, participatory planning, strategic planning, fiscal decentralization.

\section{Introduction}

Participatory Budgeting "PB" requires environmental and design factors to facilitate citizen engagement in public affairs. Therefore, this paper aims at examining how far can participatory mechanisms; that have been recently implemented in Egypt, especially through international programs; catalyse or 
contribute to societal changes in terms of governance, development, and democracy in the region. It also explores whether participatory processes are consistent with Egyptian local administrative law. This would be achieved through the paper by first presenting an overview on participatory budgeting process. This would be followed by an analytical comparison between successful worldwide case studies and the attempts that have been carried out in the different governorates in Egypt regarding the different aspects of the participatory budgeting including the initiation and implementation stages, financial aspects, citizen and governmental participation, legal, and territorial dimensions. These were the main dimensions upon which the Participatory Budgeting process has been analysed by the report published by the UN Habitat [1]. Based on this analysis, the paper would deduce guidelines that can help in the successful implementation of this powerful tool that would ultimately support the decentralization initiation in Egypt.

\section{Overview on participatory budgeting process}

\subsection{Historical background}

A historical analysis of "PB" results in the identification of three major stages. The first, dating from 1989 to 1997, was marked by experimentation, in which new forms of managing public resources were "invented". This first occurred in Porto Alegre and in other few cities such as Santo André (Brazil), and Montevideo (Uruguay). The second stage, called the Brazilian spread, corresponds to the period from 1997 to 2000, when more than 130 Brazilian municipalities adopted the model, with marked variations. Therefore, the academic literature on "PB" in Brazil is extensive and continues to increase (see Abers [2]; Chirinos [3]; Goldfrank [4]; Shah [5]; Wampler [6]). Among the countries studied are Bolivia (Bland [7]); Peru (Chirinos [3, 8]); India (Heller et al. [9]); Indonesia (Fernandez [10]); South Africa (Yusuf [11]); and Uruguay (Canel [12]). The third stage, from 2000 to the current day, is a stage of expansion (outside Brazil) and diversification; numerous Latin American and, more recently, European cities have adopted existing models, generally with significant adaptation (Cabannes [13]).

\subsection{Defining participatory budgeting}

Participatory budgeting represents a direct-democracy approach to budgeting. It is a decision-making process through which citizens deliberate and negotiate over the distribution of public resources. The enhanced transparency and accountability that participatory budgeting creates can help reduce government inefficiency and curb clientelism, patronage, and corruption (The World Bank [14]). In order to give a more precise definition of the process, five criteria need to be added (Sintomer et al. [15]): (1) The financial and/or budgetary dimension must be discussed; participatory budgeting is dealing with the problem of limited resources. (2) The city level has to be involved, or a (decentralised) district with 
an elected body and some power over administration (the neighbourhood level is not enough). (3) It has to be a repeated process. (4) The process must include some form of public deliberation within the framework of specific meetings/forums (the opening of administrative meetings or classical representative instances to "normal" citizens is not participatory budgeting).

(5) Some accountability on the output is required.

\subsection{Key features of the participatory budget process}

The "PB" process allows each sub-area to have a voice in the annual allocation of capital investments. It entails a delegation of the statutory powers of the executive branch of local governments. There is no similar delegation of authority from the legislative branch since the city council remains the body holding the statutory authority to approve the municipal budget prepared by the executive branch and submit it to the Ministry of Finance. The key features include having an annual report on the budget, as it requires municipal officials to report on what has been accomplished with the previous year's budget, either in the plenaries or in the forums, or both, estimates of revenues and expenditures for the upcoming year are presented and the budget envelope for capital investments defined. Therefore, it is structured to ensure transparency and objectivity through an open voting system and the use of quantitative criteria at every step leading to the budget allocation (Serag Aldin et al. [16]).

\subsection{Benefits of participatory budgeting}

An extensive body of literature associates participatory budgeting with good governance outcomes. (McGee [17]; Reuben [18]; Wampler [19]). However, the "PB" has main six main benefits including: 1.Democracy, where ordinary people have a real say, 2.Transparency, as when community members decide spending a public vote, there are fewer opportunities for corruption, waste, or costly backlash. 3. Education, because community members, staff, and officials learn democracy by doing it. They gain a deeper understanding of complex political issues and community needs, 4. Efficiency, as when budget decisions are better when they draw on citizens' local knowledge and oversight. 5. Social justice, every citizen gets equal access to decision making, which levels the playing field, 6. Community, through regular meetings and assemblies, people get to know their neighbors and feel more connected to their city. Local organizations spend less time lobbying and more time deciding policies. Budget assemblies connect community groups and help them recruit members (Lerner [20]).

Therefore, international development agencies, through innumerable projects, have widely adopted "PB" as a mechanism for promoting democracy, participation, and development. Their how-to manuals or guidelines for "PB" development are readily available for the interested party (IBP [21]; UN-Habitat and MDP [22]; United Nations [23]). 


\subsection{Types of participatory budgeting programs}

Participatory budgeting programs have two main tracks. One track, "participatory budgeting public works," focuses on specific public works projects, which range from the paving of specific streets to the building of day care centers. This track captures most of the citizens' interest, because it involves the distribution of resources to specific projects. The second track, "participatory budgeting thematics," focuses on general spending policies. These policies focus on more general trends, such as allocating increased spending to a particular type of health care program (The World Bank [14]).

\section{Analytical comparisons between international and Egyptian case studies regarding the "PB" implementation}

\subsection{Initiation and implementation of a participatory budget}

The implementation of the "PB" requires some preconditions including a clear political will, the interest of civil society organizations, the amounts, stages with their respective time period, building capacities for the population and for the municipal officials, the widespread dissemination of information and prioritization of demands (Cabannes [24]). Whereas, there is no universal methodology to initiate the "PB", but there is a general framework including: first, doing a situation analysis. Second, creating a map for the local actors interested. Third, a clear analysis of the amount and origin of resources. Fourth, opening up dialogues with responsibilities of the civil society. Fifth, the design of internal regulations for the "PB".

This can best be represented by the experience of Salford in England (Report to Salford City Council Budget Committee [25]). It incorporated seven main steps including: identifying the amount available for investment, developing priorities and local ideas, transforming local priorities into city-wide ones, making adjustments for population, making adjustments for levels of needs, weighting the budget matrix, and finally determining specific allocations.

Egypt on the other side, has formulated some steps within this framework that can best be represented by the methodology introduced by the German Technical Cooperation (GTZ or GIZ) in the Participatory Development Program in Urban Areas (PDP), GTZ is assisting a number of partner ministries as well as the Governorates of Cairo, Giza, Qalyoubia and Helwan in developing and implementing participatory upgrading mechanisms of urban areas, targeting the empowerment of the civil society to cooperate with the local administration for achieving development within participatory frameworks. Their developed participatory methodology has been applied in 2005/2006 as a base for implementing the detailed plans for land lot ownership in Monshaet Naser in Cairo and for prioritizing development projects in Boulak Al Dakrour in Giza in the coming budgeting plan. This methodology included many steps starting with the comprehension of the local society through urban, economic, and social surveys, then arranging meetings with the residents for the formulation of the 
local stakeholders council and for setting the requirements, then trust building through satisfying some crucial requirements. This council begins by forming committees for the different geographical areas and for the first priority needs. They then arrange workshops to prioritize the proposed projects and define the roles, and responsibilities of budgeting, implementation and follow up through meetings with the local society. The society representatives would then meet with the officials to finalize the plan technically and decide their external resources. Based on this, the local administration proposes a detailed urban plan for the approved projects on the district level, which would be finally presented again to the local society, which again participates in the implementation and the follow up phases (Abdelhalim [26]).

\subsection{Financial dimension}

The first concern in this part is the percentage of the total municipal budget that should be integrated within the "PB" process. In General, it is between 2 to $10 \%$ of the executed budget. However, few cities put more and few like Mundo Novo or Porto Alegre, discuss at least technically 100 percent (Cabannes [27]).

The distribution of the budget in Egypt is as follows: $10 \%$ of the funds for the main capital city, $30 \%$ of the funds are for the common projects between Markazs, $60 \%$ of the funds are for the "Markazs" (half for the common projects between the villages and the other half is for the villages. However, it should be noted that none of these allocated funds reflect the real needs or priorities of the community, as they just conduct a superficial process that never come into implementation, although sometimes preset by meetings with community representatives (Abdel Aty [28]).

The second concern is with the process of distribution whether according to the geographical region or according to the service sector, which in general has to be decided through a participatory process together with defining the budgeting criteria. For example, in Icapui, thematic assemblies (education as an example), represent in the process of "PB" a space of debate with social sectors. These meetings deal with the issues of general interest to the population, as well as municipal policies and programs on a specific topic. From each thematic group, two representatives and two alternates are named to participate in the participatory budget forum (Avritzer [29]). In Egypt, in Alfent village in Beni Suef, meetings attended by the local popular and local executive councils have been arranged together with the civil society representatives to prioritize their needs through sketching very primitive maps to facilitate the participation of all. Another example for setting the priorities criteria can be found in the case of $\mathrm{Al}$ Rozaikat in Qena, where the local popular council and the executive leaderships have set defined criteria for projects prioritization based on fulfilling the needs of the majority especially the marginalized groups, the availability of the resources and the coherence with national strategies (Care International [30]).

The third concern is the decision making power concerning the lines of the budget and the amounts to be debated, which is generally voted upon by the city council or equivalent body. The same case happens for the proposed budget matrix which results from the "PB" process as in the Brazilian system. In Egypt, 
the "Municipal Initiative for Strategic Recovery, Misr" has proposed a participatory methodology which resulted in considering the district level the main level for setting the local needs that are collected from its incorporated villages, and then integrate these with the comprehensive district strategy. There was also an attempt to incorporate all district strategies based on these participatory approaches within the national plan (2007-2011), but unfortunately, it did not take place, due to the lack of the true political will (The World Bank [31]).

The fourth concern is ensuring the accountability in the participatory budget which can be undertaken through many ways including: the public hearing with explanations from decision makers to the population, brochures or newspaper inserts, or placing the results of the "PB" on the website of the municipality such as that in Brazil, Latin America, and Europe. In Egypt, the Arment district in Qena is an example, where the local popular and executive councils have made presentations about their achievements and the challenges they face. The local community has also presented their requirements to dedicate part of the coming budget for fulfilling these needs. This kind of meetings has been organized to be monthly repeated for monitoring and follow up (Care International [30]).

\subsection{Participatory dimension}

The right to participate in the "PB" process differs from one country to another. In Brazilian cities, it is a universal right to participate in a voluntary, individual and direct manner not necessarily through community, union, or other representatives, whereas the remaining Latin American cities and some European cities such as Spain encourage participation through representatives of existing organizations which reflect what is called "community or associative representative democracy" (Cabannes [32]). In Egypt, there have been recently many projects that foster the residents' participation, especially in projects funded by international organizations such as the GIZ (GTZ) in a number of informal settlements, as well as the Agha Khan in Darb Al Ahmar project through giving loans for residents to promote and enhance their small artifact projects or for the rehabilitation of their houses through non-governmental organizations (AbdeI-Fattab and Abdelhalim [33]). However, the main problem is that such projects that have already taken place did not guarantee the representation of all the different residents' categories, and was characterized by being biased. In addition, the discussed budget was not a part of the national budget but was rather an external fund that was not invested in the right tracks.

As for monitoring the execution of the budget and the approved projects, it should be exercised according to each city through mechanisms including: the participatory budget council, as in Cordoba, Caxias do Sul and Icapui, a specific commission as in Porto Alegre, residents and neighborhood associations as in Caxias do Sul, specific commissions of community organizations as in Parish Board in Cuenca, or finally as a specific entity which oversees the activities of public authorities as in Bobigny (France). Cabannes [32]. In Egypt, through the decentralization initiative project, which has been applied in Abu Homos and Shubrakheit in Beheira Governorate, the local popular and executive Council has 
carried out the development plan for the year 2008/2009 through the participation of 30 representatives from the different residents; categories including 3 youths and three women. Their role was not only limited to envisioning the real society needs, it has extended to the follow up during the implementation phases together with quality assessment of what has been accomplished, which enhanced the communication between them with the civil society and the governmental entities. However, there was not any effective participation concerning taking decisions about the budget allocation (AECOM [34]).

It is worth mentioning that the role of the local government is crucial in this process, as it is decisive in each stage from priorities' determination to decisions' implementation. Most importantly, its role is vital as it offers the administrative apparatus of the decisions made through participatory processes, together with creating its mechanisms. Although, this was developed in many cities all over the world, Egypt is still developing its local administration law to clearly dedicate part of its national budget to be completely decided by the local residents through participatory processes.

Concerning the integration of the private sector in the "PB" process, their formal participation has been limited. Nevertheless, in several cities the formal private sector sometimes votes in decision-making budgeting processes. Therefore, for example, the industrial, commercial, and service sectors are part of the Congress of the City in Belem, with three of the 50 representatives. The water and sanitation company (SAAE) has a delegate in the Municipal Participatory Budget Forum in Icapui. Santo Andre, located in the industrial heart of the metropolitan region of São Paulo, invited representatives from the petrochemical and metallurgical sectors to participate in the long-term strategic planning process, called "City of the Future". These actors, organized through a commission, can now vote in the Participatory Budget Committee of the city. In Egypt, one of the fewest successful examples in integrating the private sector has been applied but in a different way. In other means, the private sector is the main actor that has fulfilled its aims through public participation to guarantee its success, as in the case of Siwa Sustainable Private Development Initiative This project was initiated in 1997 constituting many projects for the local society to reduce poverty in line with the natural environmental and cultural conservation. It is worth to highlight that these initiatives have formulated its plans based on participation from power groups in the local society to ensure the sustainability and the right implementation of their proposed plans (EQI [35]). This means that the "PB" framework did not exist, but the private sector has conceived its vital role in decision making, to assure that their allocated budget would be fully supported by the local society, that could have been a barrier against its success if not fully integrated in their plans.

\subsection{Normative and legal dimension}

Concerning the legalization of the "PB", it has to be institutionalized by municipal orders or decrees approved by the city council to avoid top down decision making, bureaucratization, and political co-operation, together with 
preserving the dynamics of the process. This is the case in most cities which practice the "PB", although this is not the case in Brazilian cities, in which the "PB" depends on the will of the local government and the mobilization of the population. But this is an exception, and cannot be generalized for other cases due to the previous reasons. In Egypt, there has been a good attempt in establishing the "local stakeholders" council for participatory planning in Boulak Al Dakrour in Giza. The concept here was based on having this council as a common actor between the elected local popular council and the appointed local executive council. The fact that has broadened the participation of the different categories including the natural leaders, women representatives, youth representatives, in addition to the civil organizations and the local private sector. Therefore, this council can definitely represent all the local community which regularly communicates with all residents through smaller committees to interpret all problems and cases, besides the follow up and monitoring during the implementation phases. This model for integrating the participatory planning processes within the institutional framework for local administration is one of the first steps towards the legalization of the "PB" (Abdelhalim [26]).

\subsection{Territorial dimension}

De-concentration of municipal services and decentralization of power within the city are strongly correlated with the "PB" processes. There is not a unified rule to state which process has to precede the other, or even to optimize the number of regions that guarantees the proper functioning of the "PB" process. In general, the regions that are part of this process tend to be smaller than the existing administrative divisions to bring the citizen closer to the public authority. For example, in Belem in Brazil with population (1.3 million), the eight administrative regions were subdivided into 28 micro-regions. In Egypt, the smallest unit that can take part of this process is the village unit, which varies in its area and population with big ranges along the different governorates, the fact that requires strong legislative framework to guarantee the true participation in this process.

\section{Discussion and conclusions}

The above analysis has presented a comparison between successful examples worldwide that have taken serious actions towards the true application of the participatory budgeting processes with the best Egyptian cases that have so far tried to integrate the main concepts incorporated within this process. It can be evidently clear that there are many gaps that have to be fulfilled all through the different dimensions that constitute the "PB" process to enable achieving the developmental goals based on true democracy. These gaps can be summarized as follows:

First, the initiation and the implementation of the "PB": it is obvious that although the best cases in Egypt have implemented clear defined steps, however, they only incorporated the "PB" in the procedures of the participatory process as 
a whole without precise discussion for amounts or specific allocations to be decided by the local citizens themselves. In other means they implemented the concept only, without detailing what exactly should be done with the budget.

Second, the financial dimension: it can be easily concluded that to succeed to apply a successful "PB", there should be a clear legislative framework that guarantees that at least a certain percentage of the budget is allocated to projects proposed by the public and according to their proposed decided priorities that are selected through a participatory process, and this still does not exist in Egypt.

Third, the participatory dimension: this is considered a vital factor in the "PB" process. Accordingly, in order to sustain a coherent structure for this process, many considerations have to be fulfilled including: the true representation for all the categories in the society without excluding any particular groups. In addition, the participation for all these groups should not be limited to the decision making phases and the final budget allocation but should be extended to the implementation, follow up and monitoring phases. In addition, it is crucial that the government creates its flexible administrative framework to guarantee the sustainability of this process. Finally, it has been found that integrating the private sector in this process can definitely ensure directing their investments in the right track and guarantees the residents' support, the fact that maximize the benefits for all incorporated stakeholders.

Fourth, the normative and legal dimension: in countries, like Egypt, where the decentralization is still initiating its first attempts towards achieving true democracy, nothing will sustain the "PB" process except accrediting local administrative laws that clarify precisely all the steps incorporated within the process and specifically declares the exact roles and rights of all stakeholders.

Fifth: the territorial dimension: It is certain that in Egypt, the "PB" process should be accompanied with the decentralization process, which has actually been initiated as part of the national strategy, but has not yet yielded in any remarkable results. Therefore, it is essential to note that the application of the "PB" process is strongly correlated to decentralizing on the different administrative levels.

In general, it can be perceived that participation in developing countries and especially in Egypt is still inadequate. It tends not to be broadly representative of the population, and it fails to involve meaningful dialogue that affects public decision making. Civil society and NGOs can play an important role in improving participation. Even in Porto Alegre, where citizen involvement is most direct, an active civil society aided the process of citizen participation. At the same time, NGOs must take into account the government's attitude toward participation and find ways to reduce the perceived costs and increase the perceived benefits of participation (Moynihan [36]).

Finally, it is important to refer to the factors that ensure the sustainability of the "PB" process, based on these successful worldwide case studies. These mainly include the empowerment of the population and its understanding of the importance of the process, which necessitates having a true society needs' prioritization based on awareness raising and educational efforts regarding the true application of this process. In other means, if all actors can foresee the 
benefits of applying such process form politicians, technicians, local stakeholders,....etc, it will definitely be sustainable. Even the revenues of the resources that the international organizations contribute would be best maximized only through the citizens' productive participation in the decision making process and the local management. Accordingly, there should be an emphasis on sustaining the flexible and the evolutionary nature of this process to permit its self- regulation through a normative legal framework.

\section{References}

[1] UN Habitat, "72 frequently asked questions about participatory budgeting", AH Editorial, Quito, Ecuador, 2004.

[2] Abers, R. N., Investing local democracy: Grassroots politics in Brazil, Boulder: Lynne Rienner, 2000.

[3] Chirinos S. L., Participación ciudadana en gobiernos regionales: El caso de los consejos de coordinación regional, In Grupo Propuesta Ciudadana (Ed.), La participación ciudadana y la construcción de la democracia en América Latina (pp. 189-222), Lima: Ser, Consode, Oxfam, Grupo Propuesta Ciudadana, Participa Peru, DFID, EED, and USAID-Peru, 2004.

[4] Goldfrank, B., Lessons from Latin American experience in participatory budgeting. Paper presented at the Latin American Studies Association Meeting, March 15-18, 2006, San Juan, Puerto Rico., p. 13, 2006.

[5] Shah, A. (ed.), Participatory budgeting, Washington, DC: World Bank, 2007.

[6] Wampler, B., Participatory budgeting in Brazil: Contestation, cooperation, and accountability. University Park PA: Penn State University Press, 2007.

[7] Bland, G., The Popular Participation Law and the emergence of local accountability. In Bolivia: From patronage to a professional state: Vol. 2, Bolivia institutional and governance review, Washington, DC: World Bank, pp. 82-110, 2000.

[8] Chirinos, L. A., Civil society and successful accountability in Peru. In G. Bland, \& C. J. Arnson (eds.), Democratic deficits: Addressing challenges to sustainability and consolidation around the world. Woodrow Wilson Center reports on the Americas \#21 (pp. 105-133). Washington, DC: Woodrow Wilson International Center for Scholars and RTI International, 2009.

[9] Heller, P., Harilal, K. H., \& Chaudhuri, S., Building local democracy: Evaluating the impact of decentralization in Kerala, India, World Development, 35(4), 626-648., 2007.

[10] Fernandez, J., Indonesia participatory budgeting efforts, Paper presented at the LogoLink International workshop on resources, citizen engagement and democratic local governance, Porto Alegre, Brazil, 2004.

[11] Yusuf, F., Community participation in the municipal budget process: Two South African case studies. Paper presented at the LogoLink International Workshop on Resources, Citizen Engagement and Democratic Local Governance, Porto Alegre, Brazil, 2004. 
[12] Canel, Municipal decentralization and participatory democracy: Building a new mode of urban politics in Montevideo City? European Review of Latin American and Caribbean Studies, 71, pp. 25-46, 2001.

[13] Cabannes Y. (c), Participatory budgeting: a significant contribution to participatory democracy, Journal of Environmental Urbanization, 16(1), pp.27-46, 2004.

[14] The World Bank, Participatory budgeting, public sector governance and accountability series, ed. Shah A., Washington, D.C., 2007.

[15] Sintomer, Y., Herzberg, C., Röcke A. (eds.), Participatory budgets in a European comparative approach. Volume II (Documents), Berlin, Centre Marc Bloch /Hans-Böckler-Stiftung / Humboldt-Universität, 2005.

[16] Serag Aldin et al, Assessment of participatory budgeting in Brazil, Harvard University Graduate School of Design Center for Urban Development Studies, Inter-American Development Bank, Washington D.C, 2005.

[17] McGee R., Legal frameworks for citizen participation: a synthesis report, LogoLink report, Institute for Development Studies, University of Sussex, Brighton, United Kingdom, 2003.

[18] Reuben W., The role of civic engagement and social accountability in the governance equation, Social Development Note 75, World Bank, Washington, DC, 2003.

[19] Wampler B., A guide to participatory budgeting, International Budget Project, Washington, DC, 2000.

[20] Lerner J., Participatory budgeting building community agreement around tough budget decisions, Wiley Periodicals, Inc. National Civic Review, DOI: $10.1002 /$ ncr.20059, A Publication of the National Civic League, 2011.

[21] IBP (International Budget Partnership), Participatory budgeting. $<$ http://www.internationalbudget.org/themes/"PB"/index.htm>, 2009.

[22] UN-Habitat and MDP (United Nations Human Settlement Program and Municipal Development Partnership Eastern and Southern Africa), Participatory budgeting in Africa: A training companion. Nairobi: UNHabitat, 2008.

[23] United Nations, Participatory planning and budgeting at the subnational level, New York: United Nations, 2005.

[24] Cabannes, Y., Conceptualization sobre presupesto particpativo a partir de experiencas latinoamericanas, Proceedings from International Seminar on "Participatory Budgets in the Bolivian Context", UMP-LAC, working paper no. 130, pp. 81-99, 2003.

[25] Report to Salford City Council Budget Committee, Community pride initiative, building a people's budget, matrix study", Copyright CPI bridget@,communitybride.org.uk, 2003.

[26] Abdelhalim K., Participatory upgrading of informal areas: A decisionmakers' guide for action", PDP (Participatory Development Programme in Urban Areas in Egypt), pdf format, http://www.egypt-urban.de, 2010.

[27] Cabannes, Y., Colección de recursos sobre Presupuestos Participativos para facilitar las transferencias interregionales. Quito, PGU-ALC, UN- 
HABITAT, UNDP. www.pgualc.org (Incluye: Biblioteca digital, Instrumentos Técnicos y Normativos, Experiencias de 14 ciudades ilustrativas, Directorio), 2004.

[28] Abdel Aty A., Challenging limitations for achieving decentralization in terms of participatory planning in developing countries, case study: Egypt, Proc. of the Fifth international Conference of Sustainable Development and Planning, New Forest, U.K., pp. 699-710, 2011.

[29] Avritzer L., Participatory institutions in democratic Brazil, Woodrow Wilson Center Press, USA, 2009.

[30] Care International, Democracy and governance, PPDG (partnership program for democracy and Governance) project, Beni Suef, Qena, Luxor", Care Egypt, http://www.care.org.eg, 2010.

[31] World bank, A poverty reduction strategy for Egypt, Ministry of Planning, Government of the Arab Republic of Egypt, Social and Economic Development Group, Middle East and North Africa Region, http://www.undp.org.eg, 2004.

[32] Cabannes Y., Participatory budgeting: conceptual framework and analysis of its contribution to urban governance and the millennium development goals, Regional Office for Latin America and the Caribbean, Urban Management Program, UN Habitat, Quiti, Ecuador, 2004.

[33] AbdeI-Fattab K. \& Abdelhalim A.I., Conservation in Islamic Cairo" and The Arab Bureau of Design and Technical Consultations/ "The Rehabilitation and upgrading of historic Cairo" both in Aga Khan Award for Architecture, The Expanding Metropolis: Coping with the Urban Growth of Cairo", Proc. of Seminar Nine (Aga Khan Award for Architecture/Concept Media, Singapore, pp. 49-53 and pp. 54-90, 1984.

[34] AECOM, http://www.aecom.com

[35] EQI (Environmental Quality International), Siwa Sustainable private development initiative: environmental, social and economic impact, International Finance Corporation (IFC), Egypt, 2005.

[36] Moynihan, D.P., Normative and instrumental perspectives on public participation: Citizen Summits in Washington, D.C., American Review of Public Administration, 33 (2): pp.164-88, 2003. 